\title{
Ocorrência de Pbyllocnistis citrella Stainton (Lepidoptera: Gracillariidae) em citros no Estado do Acre, Brasil
}

Marcílio José THOMAZINI ${ }^{1}$; Elizângela Sampaio de ALBUQUERQUE ${ }^{1}$

\section{RESUMO}

Neste trabalho é relatada a ocorrência do minador dos citros, Phyllocnistis citrella Stainton, em citros no estado do Acre, mais precisamente no município de Rio Branco. Também é feito o registro do parasitóide Horismenus sp. (Hymenoptera: Eulophidae), proveniente de pupas do minador.

\section{PALAVRAS-CHAVE}

inseto, minador dos citros, parasitóide, Amazônia Ocidental

\section{Occurrence of Phyllocnistis citrella Stainton (Lepidoptera: Gracillariidae) in citrus in the state of Acre, Brazil}

\begin{abstract}
This paper records the occurrence of citrus leafminer, Phyllocnistis citrella Stainton, in citrus plants in the state of Acre, at Rio Branco County. The parasitoid Horismenus sp. (Hymenoptera: Eulophidae) is also registered emerging from pupae of the leafminer.
\end{abstract}

\section{KEYWORDS}

insect, citrus leafminer, parasitoid, Western Amazon

${ }^{1}$ Embrapa Acre, C. Postal 321, 69908-970, Rio Branco, AC, Fone 682123200, marcilio@cpafac.embrapa.br 
O minador dos citros, Phyllocnistis citrella Stainton, é uma praga de origem asiática e se difundiu rapidamente pelo resto do mundo graças, principalmente, ao comércio de mudas. No Brasil, esse inseto foi registrado pela primeira vez em 1996, no Estado de São Paulo (Prates et al., 1996), sendo que outros estados também constataram a sua presença (Cônsoli, 2001), inclusive na região Amazônica, com alta incidência em municípios do estado do Amazonas (Lopes et al., 2002).

Esse inseto causa danos aos citros porque a lagarta consome folhas de brotações novas, reduzindo a produtividade. Contudo, os danos indiretos podem ser os mais severos, porque o dano causado pelo inseto aumenta a infestação da bactéria do cancro cítrico, Xanthomonas axonopodis pv. citri (Chagas et al., 2001).

Os parasitóides são importantes agentes de controle natural desta praga, sendo que Schauff et al. (1998) relataram mais de 80 espécies atacando P. citrella no mundo. No Brasil, Costa et al. (1999) determinaram algumas espécies de parasitóides para o estado de São Paulo.

No estado do Acre, a cultura dos citros, apesar da pequena área plantada, representa a segunda maior área em frutíferas, perdendo apenas para a banana. O plantio é realizado em pequena escala, principalmente em chácaras e pequenos sítios. Praticamente não há controle de pragas e grande parte das mudas vem de outros estados.

Como parte de um projeto de determinação dos principais insetos e ácaros que ocorrem na cultura de citros no estado do Acre, este trabalho teve como objetivo relatar a ocorrência do minador dos citros na região de Rio Branco, AC.

As coletas foram realizadas em um plantio experimental de citros com 0,5 ha e dois anos de idade, sem aplicação de produtos químicos, na Embrapa Acre ( $\$ 9^{\circ} 58^{\prime} 22^{\prime \prime}$ e W $67^{\circ} 48^{\prime} 40^{\prime \prime}$ ), município de Rio Branco, AC, entre os meses de outubro de 2003 a janeiro de 2004.

Foram coletadas folhas de brotações novas de limão, tangerina e laranja, com presença de lagartas ou pupas do minador, e levadas para o Laboratório de Entomologia da Embrapa Acre. No laboratório as folhas tiveram seus pecíolos envolvidos em algodão umedecido para evitar ressecamento, sendo individualizadas em placas de petri e acondicionadas em sala climatizada $\left(25 \pm 2^{\circ} \mathrm{C}, 60 \pm 10 \%\right.$ de umidade relativa $\mathrm{e}$ $12 \mathrm{~h}$ fotofase). Diariamente foi verificada a emergência de adultos do minador ou de algum parasitóide.

Foram obtidas 139 pupas, das quais emergiram 52 mariposas $(37,41 \%)$ e quatro parasitóides $(2,88 \%)$. O restante das pupas $(59,71 \%)$ morreu. Esse alto índice de mortalidade foi devido, principalmente, ao ressecamento das folhas, mesmo com a utilização de algodão umedecido nos pecíolos.

O adulto do minador foi confirmado como sendo a espécie P. citrella. O comércio de mudas de citros não certificadas, provenientes de outros locais nos quais o minador está presente, principalmente do estado de São Paulo, é uma das prováveis causas da presença da praga no Acre. A possibilidade da entrada do inseto pelas fronteiras da região Norte também é uma hipótese plausível (Cônsoli, 2001).

Os parasitóides foram identificados como sendo do gênero Horismenus (Hymenoptera: Eulophidae). Schauffet al. (1998), em revisão dos gêneros de parasitóides (Hymenoptera: Chalcidoidea) de $P$. citrella, relata que Horismenus é muito comum no Novo Mundo.

Sá et al. (2000) registraram que Horismenus sp. compreendeu apenas 2,05\% dos parasitóides coletados em citros em Jaguariúna, SP. O baixo índice de parasitismo encontrado foi relatado também por Nascimento et al. (2000) em citros em Seropédica, RJ, onde apenas $0,24 \%$ das larvas de P. citrella estavam parasitadas por Horismenus sp. No entanto, nesse mesmo local, Rodrigues et al. (2002) encontraram valores mais altos $(21,5 \%)$ de parasitismo de Horismenus sp. em pupas do minador. No Amazonas, Horismenus sp. foi o parasitóide encontrado em maior porcentagem em citros, predominando nas épocas seca e chuvosa (Lopes et al., 2002).

Este é o primeiro relato da presença de $P$. citrella e de seu parasitóide Horismenus sp. no estado do Acre, acrescentando mais essa região à lista de locais onde o minador dos citros está presente.

Apesar deste comunicado da presença do minador no Acre, o dano deste inseto já havia sido constatado em citros, na Embrapa Acre, em anos anteriores, por meio de observações pessoais dos autores. No entanto, não houve uma coleta sistemática e a identificação do material.

É necessário verificar, em pesquisas posteriores, o nível de infestação da praga em diferentes materiais cítricos e em outras regiôes do Estado, além da presença de possíveis hospedeiros alternativos, bem como o efeito dos fatores bióticos e abióticos na dinâmica populacional do inseto. Também será necessário utilizar um novo método de armazenamento das folhas em laboratório para evitar o alto índice de ressecamento.

\section{AGRADECIMENTOS}

Ao Dr. Valmir Antonio Costa, pesquisador do Laboratório de Controle Biológico, do Centro Experimental do Instituto Biológico, em Campinas, SP, pela identificação do minador e do parasitóide.

\section{BIBLIOGRAFIA CITADA}

Chagas, M.C.M.; Parra, J.R.P.; Namekata, T.; Hartung, J.S.; Yamamoto, P.T. 2001. Phyllocnistis citrella Stainton (Lepidoptera: Gracillariidae) and its relationship with the citrus canker bacterium Xanthomonas axonopodis pv citri in Brazil. Neotropical Entomology, 30 (1): 55-59.

Cônsoli, F.L. 2001. Lagarta-minadora-dos-citros, Phyllocnistis citrella (Lepidoptera: Gracillariidae). In: Vilela, E.; Zucchi, R.A.; Cantor, F. (Eds). Histórico e impacto das pragas introduzidas no Brasil. Holos, Ribeirão Preto. p. 23-30. 
Costa, V.A.; Sá, L.A.N de.; LaSalle, J.; Nardo, E.A.B. de; Arellano, F.; Fuini, L.C. 1999. Indigenous parasitoids (Hym., Chalcidoidea) of Phyllocnistis citrella Stainton (Lep., Gracillariidae) in Jaguariuna, Sao Paulo State, Brazil: preliminary results. J. Appl. Ent., 123 (4): 237-240.

Lopes, C.M.D.; Ronchi-Teles, B.; Silva, N.M. da. 2002. Monitoramento de Phyllocnistis citrella (Lepidoptera: Gracillariidae) e o levantamento de seus parasitóides no Amazonas. In: Gato, A.G.; Ronchi-Teles, B. (Org.). Coletânea dos trabalbos da CDSV/AM. MAPA/DFA-AM, Manaus. p. 111116.

Nascimento, F.N. do; Santos, W. da S.; Pinto, J. de M. 2000. Parasitismo em larvas de Pbyllocnistis citrella Stainton (Lepidoptera: Gracillariidae) no Estado do Rio de Janeiro. An. Soc. Entomol. Brasil, 29(2): 377-379.

Prates, H.S.; Nakano, O.; Gravena, S. 1996. A "minadora das folbas de citros" Phyllocnistis citrella Stainton, 1856. CATI, Campinas. 3p. (Comunicado Técnico, 129).
Rodrigues, W.C.; Cassino, P.C.R.; Silva, P.R.R. 2002. Registro de ocorrência de Galeopsomyia fausta (Hymenoptera, Eulophidae), parasitóide de Phyllocnistis citrella (Lepidoptera, Gracillariidae), no município de Seropédica, RJ. Revista Universidade Rural, Série Ciências da Vida, 22 (2): 99-102.

Sá, L.A.N. de; Costa, V.A., Oliveira, W.P. de; Almeida, G.R. de. 2000. Parasitoids of Phyllocnistis citrella in Jaguariuna, state of São Paulo, Brazil, before and after the introduction of Ageniaspis citricola. Scientia Agricola, 57 (4): 799-801.

Schauff, M.E.; LaSalle, J.; Wijesekara, G.A. 1998. The genera of chalcid parasitoids (Hymenoptera: Chalcidoidea) of citrus leafminer Phyllocnistis citrella Stainton (Lepidoptera: Gracillariidae).Journal of Natural History, 32: 1001-1056.

\section{RECEBIDO EM 12/02/2005 ACEITO EM 17/10/2005}


